\title{
Captive insurers as employee benefit risk funding vehicles
}

Received: 28th May, 2003

\section{Tony Salter}

is a consultant in the international consulting practice of Mercer in London where he advises multinational companies on employee benefits risk financing. He has worked in employee benefits administration and consultancy and in insurance management consultancy. He is an associate of the Pensions Management Institute (1976) and an affiliate of the Institute of Actuaries (2000).

\begin{abstract}
In the last 30 years there has been a significant, if uneven, growth in the practice of using captive insurance companies as employee benefit risk funding vehicles. This was due to the corporate need to reduce insurance costs in more difficult economic conditions, but also to obtain financing capacity for 'uninsurable' benefit risk, a problem compounded by the events of September 2001. The use of captive insurers for benefit funding has been impeded by tax and legal constraints in certain jurisdictions, particularly in the USA. This situation has now changed as a result of a more 'liberal' application of US tax and employment law and this may encourage the wider use of captives to fund benefit risks.

This paper attempts to give a historical perspective to the role of captives in employee benefit risk financing. It examines the notion of corporate risk, implicit in risk management objectives and employee benefit risk cost, as well as what is entailed in maintaining a captive as a viable profit centre. It presents a case history of a benefit risk transfer to a captive and offers some tentative conclusions about the future role of captives in funding benefit risks.
\end{abstract}

Keywords: captive insurers; cost of corporate risk; reducing employee benefit risk cost; captive insurance transactions; risk shifting; risk distribution; financing capacity for 'uninsurable' benefit risk; funding employee benefits in a captive

Tony Salter

Mercer Human Resource Consulting, Telford House, 14 Tothill Street, London SW1H 9NH, UK.

\section{Introduction}

Since about the mid-1970s there has been a significant, if somewhat uneven, increase in the use of captive insurance companies to fund employee benefit risks. This paper examines the reasons for this development, as well as some of the obstacles which have impeded, or slowed down, its progress.

Among the reasons for funding benefits in a captive are the opportunity to reduce insurance costs, to obtain financing capacity for 'uninsurable' benefit risks and to involve corporate risk management in the evaluation and treatment of benefit risks. Among the obstacles are certain tax and legal constraints which often arise from the attitudes of tax, or regulatory authorities, in the domicile of the captive or that of the parent corporation. These considerations, positive and negative, comprise the principal elements in what we may term the benefits and cost 
equation of using a captive for risk financing.

The paper will also briefly consider the growing role of captives in financing global benefits risk for multinational corporations. This development has led to a somewhat theoretical debate about whether a captive or a conventional multinational experience pool is the optimal financing vehicle for global benefits risk. In practice, as the author will try to show, the most appropriate benefit financing arrangement in most cases will probably be somewhere between these artificially polarised alternatives in the form of a risk financing construct composed of elements of each.

\section{What is a captive insurer?}

The Captive Insurance Company Directory defines a captive insurer as:

'a closely held insurance company whose business is primarily provided by and controlled by its owners, and in which the original insureds are the principal beneficiaries'. ${ }^{1}$

Captive insurers normally:

— are wholly owned subsidiaries of a trading company or partnership group;

- deal almost exclusively with the risks of the owners;

- are established under insurance principles, requiring proper premiums, adequate claims reserves and access to the reinsurance market;

- are operated in a fiscally efficient manner.

Captives originated in the mid-19th century when the first mutuals or association captives were formed. There are different kinds of captive, defined by ownership (single-parent or group-owned captives) or by function (direct underwriting or reinsurance captives). This paper focuses on the use of single-parent (corporate-owned) composite reinsurance captives.

The prime reason for managing benefit risk in a captive is to reduce insurance costs. An insurer charges more than the cost of claims and expenses to allow a profit margin and, except in situations where protection is required against the volatility of claims, it is generally uneconomical to buy insurance. In addition to reduced insurance costs, there are also advantages for the captive. Financing benefit risk through a captive diversifies the captive's risk portfolio and increases its capitalisation due to the addition of employee benefit risk reserves. It also adds value in involving the corporate risk manager in the management of employee benefit risks.

\section{Employee benefit exposures}

The employee benefit exposures are generally those which provide financial protection to employees against the hazards of life which interfere with earning capacity. They protect employees, and their dependants, against loss of earnings, or savings, due to illness or accidental injury, disability or death.

The most common benefit exposures are:

- death in service lump sums;

- death in service dependants' pensions;

- personal accident benefits;

- short-term sickness benefits;

- long-term disability income benefits;

- medical and hospital expenses benefits;

- retirement benefits.

All, or any, of these benefits are, in principle, capable of being financed in a captive insurer. There have been some constraints in respect of retirement 
benefits, but these are primarily due to the practical obstacles of restrictive tax and insurance regulatory regimes, and the possible perceived conflict of interest between sponsoring employers and their pension trusts or foundations.

Nevertheless, longevity risks associated with retirement benefits, as well as some of the investment risks entailed in guarantees of returns and capital, have been reinsured to captives. This practice may well increase with growing corporate concern about rising pension costs and lack of capacity in annuity markets. There is also no problem, in principle, in reinsuring critical illness or long-term care benefit risks to a captive.

What is critical about these benefit exposures is that the hazards which threaten the earnings and savings of individual employees also constitute a threat to the resources, and therefore ultimately to the survival, of the business organisation, since the employer not only has to pay the benefit but to bear the economic cost of the lost production of the employee. Benefit exposures, like other corporate risks, have to be managed to protect the balance sheet and the revenue account of the business.

\section{Corporate risk management objectives}

Protection of the balance sheet and the revenue account is commonly acknowledged to be the first corporate risk management objective. The second is the reduction of the cost of corporate risk to a minimum.

What do we mean by corporate risk? The author's preferred definition is one which reflects 'upside', as well as 'downside', risk and is as follows.

'Corporate risk is the measurable probability of loss [or gain] to an organisation's earnings, assets or human capital which could arise from threats [or opportunities] in its external, or internal environment, or from its realisation of a less than [or more than] 'break even' return on the investment of such earnings, assets or human capital. ${ }^{2}$

Although few HR managers may recognise that there can be an 'upside' as well as a 'downside' to benefit risk, most risk managers do. They have to manage their captive as an independent corporate profit centre with the aim of extracting, wherever possible, an 'upside' return from managing risk. The underwriting has to be profitable or, at least, enable the captive to 'break even'. The cost of corporate risk can be said to comprise two elements:

- losses retained by the corporate group; and

- the price of transferring the risk outside the corporate group.

\section{Employee benefit risk cost analysis and treatment}

For employee benefit risk cost, these two elements can be broken down into a number of critical cost factors as follows.

- uninsured benefit losses;

- administration costs (including fees and commission paid to external service providers);

- risk reduction and loss control expenditures (eg disability claims control);

- unreturned external insurance premiums (including stop loss/excess of loss reinsurance premiums) transferred outside the corporate group;

- unrecovered investment returns on cash flow (ie on insurance premiums, reserves and dividends unpaid);

- unreinsured benefit risk losses (if any) made by the group's captive insurer(s). ${ }^{3}$ 
These critical cost factors represent a framework and a foundation for 'the analysis and treatment' of employee benefit risk cost, a procedure which can be represented simply as follows:

- identification of the exposures;

- quantification of the losses;

- treatment of the exposures by:

- pre-loss risk reduction (eg employee health assessment and/or illness prevention programmes)

- post-loss risk control (eg sickness absence intervention and/or rehabilitation of disability benefit claimants);

- financing the risk either by retention (ie self-insurance) or by transfer (usually by insurance).

These principles reflect corporate concern with the effect of loss on assets, cashflow and profitability. They also recognise that the management of risk itself involves cost. As a result, all expenditures, including insurance premiums and other risk treatment costs (eg administration and disability claims control), are analysed in terms of present resources committed against expected future returns.

Capacity for absorbing losses internally is a necessary condition for self-insurance. It depends on two factors. The first factor is an acceptable degree of volatility in benefit claims. Volatility is a function of the size of the population 'exposed to risk' (the larger the 'life exposure' the less the variation in claims) and the type of benefit. The more frequent the payments (ie income benefits as opposed to lump sums) the more even the chronological spread of loss. The second factor is the availability of tax-efficient, in-house risk funding vehicles, such as pension funds and captive insurance companies.

\section{Historical development of captive benefit risk financing programmes}

The history of captives as corporate risk funding vehicles for employee benefits goes back at least as far as the mid-1970s. The most detailed sources of information are safely locked away in corporate files. It is on record, although not in the public domain, that in 1976 an international insurance network received an enquiry from a multinational corporation about a proposed reinsurance of employee benefit exposures to the corporate group's own captive. The enquiry was not merely the result of the prompting of the 'self-insurance imperative'. The risks were already substantially self-insured through experience rating in a multinational pool with another insurance network. The objective was to increase the capitalisation of the captive through the addition of employee benefits risk reserves which were of substantial volume.

Property and casualty captive insurance operations had become highly successful risk funding vehicles by the 1970s. By the middle of that decade there was concern about the lack of insurance market capacity for the financing of property, casualty and liability risk. Reinsurance markets for these risks had hardened because of adverse experience, particularly in North America, and ways were being sought to increase captive capitalisation to solve the capacity crisis. The inclusion of employee benefits in captive underwriting programmes was one of the perceived solutions.

The kinds of arrangement which enable captives to participate in benefit risk financing fall into two broad categories namely:

- reinsurance to a captive on a free-standing basis (either directly or 
through a fronting insurer) of risks under an employer sponsored employee benefit plan; and

- reinsurance to a captive of all or part of the risks of a multinational pool. ${ }^{4}$

Virtually all forms of reinsurance transacted in the commercial reinsurance market (whether proportional or non-proportional covers) apply equally in cases where a captive reinsures a benefit plan on a free-standing basis, or where it reinsures all or part of a multinational pool.

The arrangements are generally effected under a formal reinsurance agreement between the captive (which must be licensed to underwrite the appropriate benefit risks - whether short- or long-term business) and a 'fronting insurer'. It is not generally considered prudent for a financial guarantee to be provided by the captive's parent if it (rather than an affiliate or subsidiary) is involved directly in the reinsurance transaction, because that could be deemed to remove the risk transfer (ie the 'risk shifting') element from the transaction and imperil favourable tax treatment.

Most captives without external financial support are unable to meet a 'fronting insurer's' reinsurance security requirements because of low solvency ratios and the limited spread of the business. The 'fronting insurer' has to take measures to protect itself against the possible failure of the captive to meet its liabilities. Security measures usually take the form of letters of credit from the parent company's bankers (or another independent financial institution), or a separate reinsurance arrangement which meets the approval of the 'fronting insurer' and which may consist of, or include, retrocessions from the captive to that insurer.

The fact that a captive insurance company is generally a highly economical risk funding vehicle, is in no small measure due to the tax-efficient treatment of premiums, reserves, investment income and gains. Tax treatment is only rarely the most significant factor in the benefits and cost equation of using a captive. It is clear, however, that if favourable tax treatment were to be denied then tax, on the minus side of the equation, would have a significant negative effect on capitalisation from reserves and investment returns on the plus side.

\section{Tax considerations}

The most important tax considerations for risk transfer to a captive are the deductibility of premiums and the tax-free build up of reserves for the purpose of smoothing major losses. For reasons of space this paper cannot include within its purview, except in a very general way, the taxation of profits generated by captives. Legislation aimed at taxing controlled offshore companies at the tax rate of their parent (ie controlled foreign companies or CFC legislation) has been introduced in the USA, UK, Australia, New Zealand and Sweden, and is also effective in other parts of Europe where older legislation has a similar effect on offshore insurance companies. This is a more general tax issue on which most captive owners will already have a policy, and has no more bearing on financing benefit risk through a captive than on financing other kinds of risk.

The really critical issue for the tax-free build up of reserves is usually the domicile of the captive (eg other than an annual fee requirement, there are currently no taxes payable in Bermuda). Notwithstanding this, however, a captive still has to design its reserving strategies carefully so as to reflect its contingent 
liabilities. It has to meet the reserving and solvency requirements of the local regulatory authority in its place of domicile, but also has to be aware that the tax authorities in the domicile of its parent company could challenge any premium calculation, or reserving practice, which they believe unreasonably defers payment of tax by the captive or its parent. To secure favourable tax treatment in relation to the build up of reserves, the reserving strategy has to be based on wholly credible and objectively valid techniques. A test of reasonableness, commonly applied by tax authorities in the jurisdictions of captive owners, is the comparability of the captive's reserving practice with that used by 'onshore' domestic insurers for the same class of business.

The highest proportion of captive business has developed in the USA (57.1 per cent of captives are owned by US corporations compared with 28.7 per cent by companies in Europe, 9.4 per cent by companies in the Caribbean, Canada, Latin America, Africa and the Middle East, and 4.7 per cent by companies in the Pacific Rim).$^{5}$ Accordingly, law and practice relating to captive insurance transactions has undergone a greater development in the USA than in other countries. The now almost universal legal doctrine that 'risk shifting' and 'risk distribution' are the essential tests for validating an insurance transaction originated in the US courts.

\section{Tax law and practice in the USA}

In the USA a ruling by the Internal Revenue Service (IRS) in the 1970s (Ruling 977-316) established a basis for assessing eligibility for tax deductibility of captive insurance premiums. This ruling gave rise to the 'economic family' principle. On this principle, the IRS justified disallowance of a deduction to a parent company in respect of premiums it had paid to a captive which was a member of the company's own economic family. According to the theory, there can be no risk transfer in such a transaction and therefore it does not constitute insurance. The economic family principle as a barrier to premium deductibility prevailed between 1971 and 1985 in the Carnation, the Stearns-Roger and the Beech Aircraft cases where the issue of 'unrelated business' did not arise, and in the Mobil case where it did. The decision still went against Mobil because, as the Judge argued, '... any loss will be reflected in the parent company balance sheet and profit and loss account'. Mobil's argument that the IRS's position conflicted with the legal doctrine of separate corporate entities was dismissed by the court. ${ }^{6}$ All of these cases represented a serious disincentive to the US owners of captive insurance companies to increase the volume of business underwritten by their captives.

The Humana case in 1989, however, called into question the reasonableness of using the economic family principle as a test of the validity of an insurance transaction. In this case the Appeal Court ruled that the premiums paid by a 'brother' corporation to its 'sister' insurance affiliate should be deductible because the assets of Humana subsidiaries bore no part of the economic burden of the losses sustained by a sister insurance company. According to the court, the legal test for an insurance transaction is whether there has been 'risk shifting' and 'risk distribution', not whether Humana Inc. is a common parent. In the case of purported transfer of risk from a parent to a wholly owned captive, there was no risk shifting because a critical loss by the captive would lower the value of its stock, and this would be reflected in the balance sheet of the insured, ie the parent company. The court was basing its 
judgment solely on the effect of the transaction on the captive owner's balance sheet - an approach which later became known as the 'balance sheet principle'?

The court in the Humana case also considered the implications of third party 'unrelated risks' for risk shifting. It questioned the view of the court in the earlier Gulf Oil case that the insurance of unrelated party risks enhances risk shifting with respect to related party risks, as well as that court's suggestion that if unrelated premiums represented at least 50 per cent of total premiums then risk shifting would be present. The Humana court's view was that the insurance of unrelated risks solely affected risk distribution and not risk shifting. ${ }^{7}$

A number of cases had in fact concluded, that for the 'risk distribution' test to be satisfied, 'unrelated' business of 50 per cent or more of annual premiums would be required. However, in one case (The Harper Group) there was a ruling that unrelated risk of as little as 29 per cent would suffice to demonstrate that there was adequate risk distribution for an insurance transaction to have taken place. ${ }^{8}$ Moreover, a 1996 legislative initiative, which would have required 'unrelated risks' of at least 50 per cent, was rejected by Congress. Since then the IRS has generally allowed tax deductions in cases where around 30 per cent of the captive's risks are 'unrelated' to the employer.

Since the judgment in the Humana case in July 1989, a series of rulings demonstrated tacit IRS acceptance of the doctrine that risk shifting can be present where the policyholder corporation and the captive insurer are subsidiaries of the same parent corporation. However, an important development for US captive owners occurred in December 2001. Because the courts were consistently refusing to recognise the "economic family' doctrine, the IRS in ruling 2001-31 officially recorded its decision to abandon the use of that doctrine when challenging premium deductibility. ${ }^{9}$ A natural consequence of this decision is acceptance by the IRS of the 'balance sheet' approach to the taxation of captive insurance companies, which entails recognition that risk shifting exists if the risk of loss is transferred from the insured corporation's balance sheet to the captive. The 'balance sheet' approach, as we have seen, underpins the acceptance of the principle that risk shifting is present in single parent captive insurance arrangements based on brother-sister relationships. The IRS confirmed their acceptance of this in Ruling 2002-90. It, however, still leaves insurance transactions between parents and fully-owned insurance subsidiaries open to challenge on the basis that there is lack of risk shifting and risk distribution.

The second test for an authentic insurance transaction, risk distribution has undergone further development. Some courts have indicated that risk distribution requires the spreading of risk among multiple independent policyholders (the so-called 'independent entity' requirement), whilst others have suggested that risk distribution depends on assuming risk for a substantial number of unrelated exposures ('the independent risk' requirement). IRS Ruling 2002-90, however, has now made it clear that, in the view of the IRS, both approaches equally figure in the risk distribution equation. ${ }^{9}$

In another ruling, the IRS has recognised health and life insurance benefits as unrelated exposures which supports the notion that funding employee benefits in a captive strengthens the case for risk distribution. Although these benefits are generally provided under employer-sponsored plans, the IRS considers that the ultimate 
risk in respect of the benefits is a personal financial risk borne by the employees and is therefore unrelated to the employer. ${ }^{10}$ As a result, some US corporate taxpayers are attracted to the idea that if they reinsured employee benefit risks to a captive, they would increase the proportion of their unrelated risks and would thereby secure more favourable tax treatment for financing other risks through the captive.

\section{Tax law and practice in other countries}

Moves to disallow premium deductibility have not been so successful in other parts of the world. Attempts have been made by the tax authorities in Canada and the Netherlands. In a Canadian case, Consolidated Bathurst (1985), the court decided that the separate corporate identity of the insurance subsidiary could be disregarded and ruled that premium payments were only a means to build up a reserve fund, although insurance cover for the risk was not available in the market. The Appeal Court, however, overturned the judgment on the grounds that the US 'economic family' concept could not be employed outside the USA. It "would amount to a wholesale disregard of separate corporate existence regardless of the circumstances in a particular case' and this was found to be unacceptable. There must be a shifting of risk to the captive and risk distribution if the payment of premiums was to be considered part of a genuine insurance transaction, but whether the insurance company is in the same corporate group as the insured has no bearing on risk shifting. A distinction has to be made if the parent guarantees the liabilities of the captive to a fronting insurer because it could then be called upon to fund its own claims and that would undermine risk shifting. ${ }^{6}$ There is certainly more than an echo here of the balance sheet principle.

In a case in the Netherlands, also in 1985, a court ruled against the tax authorities that tax deductibility of premiums paid to a bona fide captive located in a low tax jurisdiction should be allowed. In the UK the Inland Revenue has expressed the view that the courts would generally follow the decision of the Canadian Federal Court of Appeal in the Consolidated Bathurst case. It has stated, however, that although it will not

'disallow premiums paid to a captive as a result of the general application of the economic family argument, it should not be assumed that captive arrangements are free from challenge if they fail to provide a mechanism for the effective transfer of risk. In particular, if captives have insufficient resources to provide the level and quality of cover purportedly being offered it will be assumed that the parent must have had some non-business purpose in mind when paying premium since the payment is failing to achieve an effective transfer of risk'. ${ }^{6}$

The UK Inland Revenue admits that because of the terms of UK legislation it is '.. more concerned than the IRS to test whether a captive has the ability to meet the risks it underwrites'. It considers it important that the captive is adequately capitalised with reserves to meet its contingent liabilities, although not in a way which would unreasonably defer payment of tax by the parent company. ${ }^{6}$

\section{Legal issues}

Apart from the general issues raised by tax and insurance law in the various jurisdictions in which captives, benefit plans and plan sponsors are resident, the most critical legal issues affecting the financing of employee benefits in a 
captive are probably the fiduciary responsibilities of trustees under trust law. Trustees are required always to act in good faith in the interests of the beneficiaries of the trust. Although there is no reason in principle why use of a captive as a benefit risk funding vehicle should in any way prevent trustees from meeting their fiduciary responsibilities, it has been thought that a conflict of interest between employer and trustees could arise in practice where a plan was required to pay premiums in accordance with a stable premium rate, under a captive financing arrangement, rather than in accordance with a lower (less stable) premium rate, on a short-term basis, in the local insurance market. A potential conflict of this kind can usually be overcome, however, by persuading the trustees, or administrators, of the plan to take a longer term view of the financing of the risk, or even by the sponsoring employer undertaking to indemnify the plan against any estimated additional costs that may be incurred, as a result of the captive risk financing arrangement.

In relation to employee benefits provided under US plans, the Employee Retirement Income Security Act (ERISA), introduced in 1974, imposes constraints on benefit financing in a captive. ERISA enforces certain fiduciary obligations in respect of benefits provided for US employees which make it a prohibited transaction for an employer to insure any employee benefit liabilities with a related captive unless the captive derives at least 50 per cent of its total premiums from 'unrelated' entities. (This contrasts with the IRS viewpoint that employee benefit risks are 'unrelated' to the employer.) The US Department of Labor (DOL), however, by virtue of section 408(a) ERISA, has the power to grant a prohibited transaction exemption (PTE) in the case of certain transactions, or classes of transaction. In 2000 , the
DOL exercised the power to grant an exemption in the case of the Columbia Energy long-term disability plan where it was shown that the captive insurance transaction was beneficial to plan participants. ${ }^{11}$ A similar exemption was granted in May 2003 in the case of the Archer Daniels Midland Company (ADM) group life insurance plan which it was proposed to reinsure to the ADM Group captive. ${ }^{12}$

The importance of this second exemption is that it opens the way to a 'fast tracking' procedure (known as the EXPRO approach) for other PTE applicants. Both Columbia Energy and ADM had to wait 12 months for issue of their PTEs. The 'fast tracking' procedure requires applicants to cite at least two precedents of PTEs granted in the case of transactions of the same class and Columbia Energy and ADM should provide these precedents. ${ }^{11}$

In the Columbia Energy ruling, DOL defined the criteria for PTE eligibility in cases where the 50 per cent 'unrelated risks' test could not be met by a captive proposing to reinsure benefit risk. The criteria are as follows.

- The captive must be domiciled in the USA, or be a US branch of a captive domiciled offshore.

- The arrangement must be beneficial to employees participating.

- An 'independent' fiduciary must review the arrangement on behalf of the plan.

- The arrangement must be 'fronted' by an ' $A$ ' rated insurance company which retains the 'ultimate' risk in respect of the plan exposures.

\section{Reserves}

What exactly is meant by 'reserves'? As a result of the spread of business underwritten in any accounting period 
and the need to settle claims in respect of policy holders' losses, insurers have to establish technical reserves (or provisions) to cover unpaid liabilities incurred up to the date of account. These technical reserves fall broadly into two categories: those relating to 'unexpired risk' and those relating to outstanding claims. There is also a third category, referred to as 'deficiency reserves', which are of particular importance in the case of long-tailed exposures, such as long-term disability income benefit insurance and liability insurance for which claims may develop after significant delays.

The constituent elements of these three categories of reserves can be summarised as follows. ${ }^{13}$

- Unexpired risk reserves consisting of an 'unearned premium reserve' (sometimes referred to as an unexpired premium reserve), together with an 'additional unexpired risk reserve' required if current premium rates are inadequate to cover the cost of claims for unexpired risk.

- Outstanding claims reserves generally comprising a 'reported but outstanding claims reserve', an 'incurred but not reported claims reserve' (commonly known as IBNR) and a 'reopened claims reserve' which is a contingency reserve required for long-tailed exposures, such as liability risks, where settled claims could be reopened if additional liability arises.

- General deficiency reserves usually established to cover catastrophic losses and to provide claims equalisation, or stabilisation, reserves, where appropriate.

This kind of reserving structure presupposes that the insurer's risk portfolio in respect of employee benefit exposures is relatively mature. In other words, the insurer will have been managing these exposures for some time and will have developed a real risk-bearing capability. In the case of a captive underwriting a new risk with which it is not familiar, it would be prudent for such a risk at the outset to be substantially reinsured against the cost of extreme claims.

\section{Elements of a benefits risk transfer}

The economic value of captive benefits financing can be illustrated simply by an example. The figures shown in Table 1 are based on an actual case history of the reinsurance of a UK employer's group life insurance policy (covering the liabilities of a death in service benefit arrangement) to an 'offshore' captive belonging to the same corporate group.

Some may question whether there can be any added economic value in self-financing death in service benefits in a captive rather than in a pension fund. In considering this question the economic circumstances of the sponsoring employer, and the corporate group to which it belongs, need to be carefully considered. In many countries, for example, death in service benefits are provided for an increasing number of employees who are members of pension arrangements administered on defined contribution principles, where reserves are allocated to individual accounts. As a result, there are no 'free' (or unallocated) reserves as under a defined benefit plan that can be used to smooth fluctuations in death benefit claims.

A captive can be an appropriate corporate risk funding vehicle for death benefits in a wide range of economic circumstances. Even small companies, which find it impractical to set up their own captives, can now have recourse to benefit financing through externally administered protected cell companies 
Table 1: The economic value of captive benefits financing

\begin{tabular}{|c|c|c|c|c|c|}
\hline \multicolumn{6}{|c|}{ (All amounts in $£$ ) } \\
\hline $\begin{array}{l}\text { Renewal } \\
\text { period }\end{array}$ & $\begin{array}{l}\text { Total premium } \\
\text { for the period } \\
\text { [a] }\end{array}$ & $\begin{array}{l}\text { Total claims in } \\
\text { the period } \\
\text { [b] }\end{array}$ & $\begin{array}{l}\text { Stop loss } \\
\text { reinsurance } \\
\text { premium } \\
\text { [c] }\end{array}$ & $\begin{array}{l}\text { insurer's } \\
\text { administration } \\
\text { fees } \\
\text { [d] }\end{array}$ & $\begin{array}{l}\text { Cash flow } \\
\text { advantage } \\
\text { to captive } \\
\text { [a-b-c-d] }\end{array}$ \\
\hline $97 / 98$ & $2,100,000$ & $1,650,000$ & 84,000 & 63,000 & 303,000 \\
\hline $98 / 99$ & $2.325,000$ & $1,875,000$ & 93,000 & 69,750 & 287,250 \\
\hline $99 / 00$ & $2,550,000$ & $1,650,000$ & 102,000 & 76,500 & 721,500 \\
\hline $00 / 01$ & $2,700,000$ & $2,100,000$ & 108,000 & 81,000 & 411,000 \\
\hline $01 / 02$ & $2,850,000$ & $1,800,000$ & 114,000 & 85,500 & 850,500 \\
\hline Totals & $12,525,000$ & $9,075,000$ & 501,000 & 375,750 & $2,573,250$ \\
\hline
\end{tabular}

which provide complete legal separation of the assets attributable to each cell, similar to the rental captive model.

The case history is based on an insured arrangement with an annual average of about 18,000 lives 100 per cent reinsured to the captive under a 'quota share' agreement. An analysis of insurance premiums, expenses and claims over a five-year period, illustrates how this financing strategy benefited corporate 'cash flow'. Premiums were payable to a 'fronting insurer' annually in advance and, within three working days of receipt, were remitted to the captive. Claims were reimbursed to the fronting insurer within three working days after admission. The stop-loss insurance covered aggregate claims in each policy year exceeding the captive's self-retention limit of 120 per cent of total expected claims, without any individual or aggregate limit on the sums at risk. Table 1 shows that this risk transfer made a contribution to the captive's reserves and profits of just over $f 2.5 \mathrm{~m}$ over the five-year period (ie approximately 20 per cent of the $612.5 \mathrm{~m}$ total premium paid over that period). The figures do not make any allowance for the investment returns on the captive's reserves.

When considering the figures in Table 1, it should be borne in mind that the premiums were not based on a premium rate which was the product of 'competitive bidding' in the insurance market. The premium rate was calculated on actuarial principles with the intention that it would remain stable over a period of four to five years, subject to any fluctuations in the average age of the insured lives weighted by benefits.

Generally, in the case of smaller life exposures, captives rely on the underwriting, actuarial and claims handling expertise of the 'fronting insurer'. There is a point, of course, where such an arrangement becomes uneconomic for the captive. Depending on the scale of the exposure and the period of the captive's involvement in the management of the risk, the drive to minimise risk cost should result in the captive significantly increasing its share of the risk. In this way it would appropriate to itself a higher proportion of the unused expense and contingency margins of the fronting insurer-cumretrocessionaire. The kind of arrangement, described in the example, is consistent with a future strategy for the captive to gradually assume a greater share of the risk as its reserves increase.

\section{Determination of premiums}

The captive would then need to have an involvement in the determination of the 
premium and the structuring of reserves like any commercial reinsurer. Commercial life insurance premiums generally comprise five main components, allowing respectively for mortality experience, profit margin, investment returns, contingencies and commission. In the case of long-term disability insurance, allowances for mortality experience of claimants, recovery rates and inflation would need to be added.

The amount of premium to be calculated initially would be the 'pure risk premium', which is the amount the insurer would normally expect to pay out in each policy year. This is 'the expected claims cost' which we equate to the working layer of the risk. The expected claims cost is determined from a suitable mortality table which will indicate the estimated liability due to deaths as well as the range of fluctuations. In estimating mortality, allowance has to be made for geographical as well as gender differences and for the fact that the mortality of general populations is normally higher than that of insured lives.

If the population 'exposed to risk' is sufficiently large, and has remained reasonably homogeneous over some years, the actual claims history of the group can be used to modify the wider mortality statistics. Otherwise there will be increased reliance on wider mortality statistics modified only by occupational, industrial and situational factors and any other hazards which critically affect the nature of the risk exposure.

The actual cost of claims in any given year will obviously not equate to the fixed amount of the mathematically calculated risk premium. Claims are subject to volatility and considerable fluctuations can be expected. In terms of probability theory, claims are a random quantity - a random variable - and can assume any value between:

- the minimum cost of risk when no claims occur; and

- the maximum cost of risk when all claims (representing the total sums at risk) occur.

\section{Modelling the risk}

To try to obtain some measure of the probable variations in the claim amounts, it is prudent to carry out mortality simulations. These help to determine an appropriate level of risk retention for the captive and the amount to be allocated to contingency reserves, just as they would help a non-proportional reinsurer to determine its stop loss charge. The main types of method generally used to carry out these simulations are the Monte-Carlo method and various risk theory models. ${ }^{14}$

Expense and contingency loadings are then added to the pure risk premium to convert it into a commercial premium. These loadings to the premium basis could be, very broadly, of the order of 4 per cent for commission, 5-6 per cent for expenses and 5-10 per cent for contingencies and profits. If the premium rate is to be guaranteed for more than one year then an allowance must be made in the premium basis for a solvency margin which will generally vary from 0.1 per cent to 0.2 per cent of the sums at risk, depending on the period of the guarantee. In some countries, which have more stringent solvency margin requirements, the margin will be higher.

\section{Calculation of group life insurance reserves}

Group life insurance reserves can be divided simply into three parts as claims 
tend to be settled quickly. These are an 'unexpired premium reserve', an 'IBNR reserve' and a 'deficiency reserve' which can be quite critical if the premium rate is to be guaranteed for more than a year.

These reserves will not be significant in amount compared, for example, with long term disability insurance and will only rarely exceed two to three times the amount of the annual premiums. This assumes that the insurer will not bear the risk of any catastrophic losses resulting from multiple claims arising from a single event, such as an act of terrorism. Reserves will automatically allow for expected reinsurance recoveries for both individual peak sums at risk and aggregate losses above the insurer's retention level.

There is currently an acute shortage of capacity in the benefit risk reinsurance market, particularly for higher level exposures in respect of multiple claims arising from a single event. Accordingly, less costly internal corporate resources could, in some circumstances, represent better economic value than conventional reinsurance. Internal contingency credit lines can be backed up by an 'alternative risk transfer' (ART) solution to provide contingent capital facilities, such as a catastrophic event-triggered equity put option which would help to restore shareholder equity and solvency ratios after the event.

\section{Financing global benefit risk}

Corporate interest in captive insurers as benefit risk funding vehicles has increased as a result of the need to develop strategies for the financing of global benefits risk. Efficient global benefits financing requires a central chronological loss-spreading mechanism for the 'working layer' of the risk (ie the part representing predictable losses). Such a loss-spreading mechanism has to be sufficiently flexible to permit modification, where required, through the addition of stop loss, or excess of loss, protection against extreme claims, whether from natural causes or catastrophic events. A multinational experience pool offers an opportunity for self-insurance through its loss treatment systems, and either on its own, or in conjunction with reinsurance to a captive insurer, can usefully serve as a matrix for a central funding mechanism for global benefit risk exposures.

What is essential in the case of any risk funding vehicle, conventional multinational pool or captive insurer, is that the insurance protection purchased is relevant, that realistic investment returns can be realised on premium float and risk reserves, and that the management of the arrangement is provided at economic cost.

\section{Captive insurers versus conventional multinational pools}

In principle, a captive insurer should always be a more economically efficient risk funding vehicle than a conventional multinational pool because premiums (other than reinsurance premiums) and risk reserves are retained within the corporate group until paid out as claims. However, when trying to establish a captive financing arrangement for global benefits risk, other than through the medium of a multinational pool, a number of practical difficulties arise.

First, in countries with restricted insurance markets, captive reinsurance of employee benefits can generally only be achieved through a multinational pool. Secondly, financing global benefits risk through a captive requires an enabling network of local (fronting) insurers and this is most conveniently achieved through the medium of a multinational pool. Thirdly, a captive insurer, acting on its own, may, unless it writes a significant 
amount of third-party (ie 'unrelated') business, find it difficult to obtain in the reinsurance market stop loss, or catastrophe excess of loss, cover proportional to its risk exposure. It is usually able to purchase this protection more readily, and more economically, through a multinational pool because the international insurance network will have leverage with reinsurers as a major buyer in the reinsurance market.

If a free-standing conventional multinational pool is to be as economically efficient as a pool reinsured to a captive it must provide:

- the opportunity to purchase insurance protection proportional to the nature of the risk exposure at the same economic cost;

- parity of net investment return on all premiums and reserves; and

- comparability of management expenses, including any reinsurance commissions. ${ }^{15}$

\section{A captive as a corporate profit centre}

It will be recalled that one of the critical factors of benefit risk cost is unreinsured benefit risk losses made by the group's captive insurer. It is accordingly incumbent on risk managers to manage their captive efficiently as an independent corporate profit centre with the aim, wherever possible, of extracting an upside return from managing risk, which should not be to the detriment of other corporate profit centres.

For a captive to be profitable, or at least break even in financing benefit risk, it has to have a management strategy which incorporates the following features.

- A logical diversification of the captive's risk portfolio.
- A balanced underwriting programme for benefit risk exposures (including external reinsurance arrangements).

- The consistent use of pre-loss risk reduction and post-loss risk control strategies.

- The application of underwriting terms and conditions, including a stable pricing policy which realistically reflects the exposures to risk.

- A reserving strategy which adequately reflects the contingent liabilities.

- Effective procedures for the control of implementation and operating costs.

- A policy which fully accommodates relevant insurance, tax and exchange control legislation and practice.

\section{Conclusion}

It has been argued in this paper that captive reinsurance arrangements can help to minimise the cost of benefit risks. Tax efficiency, as we have seen, is a vitally important consideration, but whether a captive is used for funding employee benefits in any specific corporate situation should ultimately depend on whether its use is likely to result in a greater reduction in the critical factors of benefits risk cost, than would result from the use of other risk funding vehicles. It is suggested that a captive generally ought to be able to achieve higher investment income on premium float and risk reserves than would generally be credited by insurance networks in respect of multinational pools.

Notwithstanding these considerations, the decision to use a captive may still be made quite independently on grounds of corporate risk management strategy to achieve:

- financing capacity for levels, or types, of risk for which cover is not available in the insurance market; 
— involvement of the risk manager in handling employee benefit risks, together with the establishment of strategies of pre-loss risk reduction and post-loss risk control; and

- the transfer of employee benefits risk premiums/reserves to the captive in order to concentrate resources centrally for the risk financing needs of the corporate group as a whole.

In relation to financing capacity, there has, after the tragic events of 11 th September, 2001, been a growing interest in the capacity of captives to provide for additional levels of risk for which cover is not readily available in the local insurance markets. For example, the 'catastrophic event limits', recently introduced under UK group life insurance policies, have created a whole new area of 'uninsurable benefit risk'. These limits typically exclude coverage for any part of aggregate losses that arise from a single event exceeding $\mathcal{E}_{1115 \mathrm{~m}}$. There is also interest in using captives to finance previously insurable risks which can now no longer be easily placed in the insurance market, such as accidental injury, or disability, benefit losses arising from terrorist acts. The most significant renewal of interest in funding employee benefits in a captive, however, is expected to be among US corporations as a result of the granting of ERISA prohibited transaction exemptions in the Columbia Energy and ADM cases and the availability of the DOL's accelerated application and approval process. These developments in conjunction with IRS recognition of health and life insurance benefits as 'unrelated' captive business with resulting tax advantages could well act as a powerful incentive for the reinsurance of US employee benefits to captives.

From time to time, financial commentators express the view that corporate-owned captive insurance companies have an uncertain future. The statistical evidence shows, however, that despite soft insurance markets and hostile action from tax authorities and insurance regulators, the number of corporate-owned captives continues to increase. A study by a leading global reinsurer shows that in 2001, captive insurers underwrote US $\$ 25$ bn gross premiums worldwide, representing about 10 per cent of global commercial lines business. ${ }^{16}$ They ceded US $\$ 8$ bn to the global reinsurance market and invested US $\$ 138$ bn in assets. Since 1998, the captive insurance market has grown by an average of 10 per cent per annum. For 2002, most major captive domiciles reported significant growth in the number of captives and the number of domiciles has increased. ${ }^{17}$ Moreover, the rapid increase in cell captive facilities has brought captive benefit financing within the reach of business organisations throughout the 'free world'. The captive insurance company, it seems, is still generally perceived as a corporate risk management tool of great flexibility and sophistication.

(C) Tony Salter

\section{References}

1 'Captive Insurance Company Directory 1992', Tillinghast, Stamford, Connecticut.

2 Salter, T. (1998) letter published as a contribution to the 'Meaning of risk debate' AIRMIC (Association of Insurance and Risk Managers) Express, August.

3 These critical factors of risk cost are based on a concept, developed in the 1960 s by Douglas Barlow, the then risk manager of Massey Ferguson, to analyse the cost of property, casualty and liability risk exposures.

4 Between 1976 and 1983 the author helped to establish 14 captive benefit risk financing arrangements, of which eleven were reinsurances to a captive of benefit risks on a freestanding basis from benefit plans and three were reinsurances to a captive of benefit insurance policies included in multinational pools.

5 A M Best Company Inc. (2002) 'Captive Insurance Directory 2002', Tillinghast-Towers Perrin. 
6 Bawcutt, P. (1997) 'Captive Insurance Companies, Establishment Operation and Management', 4th ed, Witherby \& Co Ltd, London.

7 Humana Inc $v$ The Commissioner of Internal Revenue, US Court of Appeals for the Sixth Circuit, July 1989.

8 The Harper Group v The Commissioner of Internal Revenue, Tax Court and US Court of Appeals for the Ninth Circuit, 1992.

9 Jones, T. (2003) 'New IRS Rulings Clarify Captive Taxation', Captive Insurance Company Review, February.

10 See IRS Rulings 1992-93 and 1992-94.

11 (2003) 'US employee benefits captives', Captive Insurance Company Review, April.

12 US Department of Labor, Employee Benefits Security
Administration, Prohibited Transaction Exemption 2003-07; Archer Daniels Midland Company (2003) 'Federal Register', Vol. 68, No. 86, 5th May.

13 Salter, T. (2000) 'Financing Benefit Risks through a Captive Insurer', Benefits \& Compensation International, London.

14 Daykin, C. D., Pentikainen, T. and Pesonen, M. (1997) 'Practical Risk Theory for Actuaries', Chapman \& Hall, London.

15 Salter, T. (2001) 'Captive or pool debate', Investment $\&$ Pensions Europe, February.

16 Swiss Re (2002) 'Report on Captive Insurance Companies', Captive Insurance Company Review.

17 (2003) '2002: A record year for captives', Captive Insurance Company Review, March. 